\title{
Impact of Globalization on Higher Education in India: Issues, Challenges and Alternatives
}

\author{
Dr. Shailendra Singh ${ }^{1 *}$
}

\section{ABSTRACT}

Globalization is an umbrella term that refers to increasing global connectivity, integration and interdependence in the economic, social, technological, cultural, political, and ecological spheres. It is a unitary process inclusive of many such sub-processes, perhaps as best understood as enhanced economic interdependence, increased cultural influence, rapid advances of information technology, and novel governance and geopolitical challenges. Higher education includes certain collegiate level institutions, such as vocational schools, trade schools, and career colleges that award degrees, diplomas and certificates. Globalization of higher education has brought remarkable changes in cross-border education. Attracting a good number of international students has been fairly a strong base of educational trade that is growing rapidly around the world. India has one of the largest and most complex higher educational systems in the world. Prior to a few decades ago, due to multifarious reasons, India was unable to attract a good number of foreign students in its universities. Keeping this in mind, the Government of India has taken various steps and launched a few ambitious programmes. Now, Indian universities and other institutes are open to the global market and hope to attract foreign students. This paper examine different aspect of globalization which can usefully be viewed as challenges to higher education especially in its efforts to develop diverse ideas and demonstration of quality and systems of quality guarantee that will be useful and sustainable in this situation.

Keywords: Higher Education, Globalization, Academic Excellence.

The phenomenon of globalization, which transformed world trade, communications and economic relations in the latter part of the $20^{\text {th }}$ Century, is having a similarly profound effect on education at the start of the $21^{\text {st }}$. Student options for higher education, in particular, are no longer constrained by national boundaries. For the first time in history, large segments of the world's student population truly have access to a "global marketplace" of higher education.

\footnotetext{
${ }^{1}$ Asst. Prof. Faculty of Education, P. G. College, Ghazipur, V. B. S. Purvanchal University, Jaunpur (U.P.) India *Responding Author (C) 2016 I S Singh; licensee IJIP. This is an Open Access Research distributed under the terms of the Creative Commons Attribution License (http://creativecommons.org/licenses/by/2.0), which permits unrestricted use, distribution, and reproduction in any Medium, provided the original work is properly cited.
} 
Globalization is a process, which has affected many areas of human life, one of those being education. In the twentieth century, many developing countries have experienced growth in the educational facilities available to them due to the entry of institutions from the west. Some believe that this process is an invaluable opportunity for the people of the developing countries to raise their skills and standards of education. Others fear that it is merely a modern version of cultural imperialism that will lead to the creation of a universal, ultimately western society. No human activity has remained unaffected by globalization and education is no exception. It brings education to the front lines. In the prevailing discourse, education is expected to be the major tool for incorporation into the 'knowledge society' and the technological economy.

In educational terms, there is a growing understanding that the neoliberal version of globalization, particularly as implemented (and ideologically defended) by bilateral, multilateral, and international organizations, is reflected in an educational agenda that privileges, if not directly imposes, particular policies for evaluation, financing, assessment, standards, teacher training, curriculum, instruction, and testing. In the face of such pressures, more study is needed about local responses to defend public education against the introduction of pure market mechanisms to regulate educational exchanges and other policies that seek to reduce state sponsorship and financing and to impose management and efficiency models borrowed from the business sector as a framework for educational decision-making.

Is it possible, to give general answers to the question of how globalization is affecting educational policy and practice in India and worldwide? We believe that there can be no single answer; national and local economic, political, and cultural changes are affected by, and actively responding to, globalizing trends within a broad range of patterns. Indeed, because education is one of the central arenas in which these adaptations and responses occur, it will be one of the most myriad of institutional contexts. Hence, the answers developed will require a careful analysis of trends in education, including:

- The currently popular policy "buzz words" (privatization, choice, and decentralization of educational systems) that dive policy formation in education and prevailing research agendas based in rational organization and management theories.

- The role of national and international organizations in education, including teacher unions, parent organizations, and social movements.

- The new scholarship on race, class, gender, and the state in education (hence concerns about multiculturalism and the question of identity in education), critical race theory, feminism, post colonialism, diasporas communities and new social movements.

The current globalization of higher education creates both challenges and opportunities. The relationship between universities education and globalization gives special attention. Education will be the answer to many problems raised by globalization. Educational goals are seen to be an area of great concern in the era of globalization. It is here that universities play a crucially important role, to create better society. It is impossible to ignore the global; universities need to 
reflect on the impact of globalization. They must engage with the issues of globalization, both theoretically as analysts and researchers, and practically as academic workers involved in an increasingly globalised enterprise.

The likelihood of entry of foreign universities into India is an inevitable consequence of globalization. Top class foreign universities are anticipated to add prestige to India's higher education. The expectation is that foreign universities will bring much needed capacity and new ideas on higher education management, curriculum, teaching methods and research, together with investment. Though fear has been expressed that only commercial institutions will come to India and that Oxford and Cambridge will shy away, my guess is that top class universities will come to India, not to make profit, but to profit from the vast intellectual resources of the country. The foreign universities bill has adequate safeguards against throwing open our higher education to fortune seekers and unscrupulous business interests.

\section{INTERNATIONAL INFLUENCES IN INDIAN HIGHER EDUCATION}

If one scans the horizon of Indian higher education institutions today, the legacy of prior waves of international, if not global, influence can be seen in virtually every field. India hosts a wide variety of pre-Independence missionary institutions - colleges founded in the late $19^{\text {th }}$ and early $20^{\text {th }}$ Centuries by foreign missionaries of different faiths. St. Joseph's College Trichy, St. Xavier's Chennai, Christian Medical College Vellore, St. John College Agra, Isabella Thoburn College Lucknow, etc.

In the post-Independence era, the Indian Institutes of Technology, consciously patterned after the Massachusetts Institute of Technology in the U.S., received substantial overseas help right from the outset. With support from four donor nations, the five IITs benefited from guest faculty from outside of India, the ability to send Indian faculty for training abroad, and contributions of modern laboratory equipment and facilities. Similar international links were established by the Indian Institutes of Management: IIM-Ahmadabad, for example, still maintains strong connections with the Harvard Business School. Perhaps the most recent innovation in Indian higher education, the Indira Gandhi National Open University (together with similar, statesponsored Open Universities), drew heavily on the UK experience with distance education and the Open University concept.

\section{IMPACT OF GLOBALIZATION ON HIGHER EDUCATION}

The challenge of higher education is to make full use of the opportunities that globalization has provided. First and foremost, the marvels of technology must be fully and profitably deployed. In India, Internet connectivity for university students is still inadequate. But the massive increase in cell phones, which are becoming more and more versatile, may be the answer to India's connectivity crisis. Once full connectivity is accomplished, the students can be liberated from the classrooms and allowed to find and create knowledge. The Universities will simply have to devise a means by which it can be established that the knowledge attained is genuine and 
accurate and that it is relevant to the needs of the countries concerned. Different students in the same class may diversify themselves and enrich different branches of knowledge. The impact of globalization on higher education may be summarized in the following ways:

- Increasing interest of parents to get their children admitted to foreign educational institutions will cost us precious foreign exchange.

- Sometimes there is also the possibility of sub-standard courses being offered to the students, which may lead to cheating of innocent citizens of India.

- It will lead to the creation of three different classes of graduates - those educations in foreign universities, those from costly private domestic institutions, and those from economically weaker sections studying in government funded institutions. This will only lead to social tensions.

- In view of the nature of the globalised higher education, the commoditization of Indian higher education is bound to have an adverse effect on our culture, the ethos of social welfare and even the quality of Indian education system.

One impact of globalization on education is the urgency to develop a skilled work force at all levels to meet the demands of increasing business environment. Instead of its traditional role of providing education as a welfare measure, the state is required to facilitate privatization and deregulation in education, particularly as the quality of education provided by the state institutions has been rather poor. This is by no means undesirable, as privatization of education has helped to increase quantity as well as quality. Profiteering is a negative factor, but its evil is often offset by the timely and efficient utilization of human talent to develop competitiveness worldwide. Indians seeking employment and competing successfully is no recent phenomenon. Globalization has merely hastened the pace of migration and created better placements worldwide.

As the private sector's contribution in higher education in India is gaining in strength, India cannot take recourse to article 1.3 of the GATS that allows exemption for services provided by the government. In order to cope with the western countries, the measures required include the adoption of a credit based semester system with continuous internal evaluation. A cafeteria type option to the students for the course to be offered and facilitates of credit transfer. A majority of conventional universities in India are far behind, at least in non-professional courses. As the UGC, AICTE (All India Council of Technical Education) and other controlling agencies are not in a position to intervenes effectively and control the foreign educational institutions, the government of India has set up a committee under the NAAC, under its chairman Ram Takwale, to monitor the applying foreign universities. At present 150 foreign universities (50 from UK, 45 from Australia. 30 from USA and the rest from Canada and other European countries that have been operating in India. The UGC has decided to invite proposals from institutions that are keen on "exporting Indian education" to foreign learners under a "Study India Programme". A recent study shows that one in every 10 students studying in the US was an Indian, while less than 0.6 percent of American Students were receiving educational credit for studying in India. 
The government of India has recognized these dangerous phenomena and belatedly started the process of constituting a Committee for the Promotion of Indian Education Abroad under the Ministry of Human Resources Development, department of education. During 2001, there were 54,664 Indian students in the United States alone, with the total number abroad exceeding 10 lakhs. In contrast, there were only 7,791 foreigner students in India, mainly from the developing countries like Bangladesh and countries of South and East Asia. Globalization and commercialization of education has thus become a reality and, India being a signatory to the WTO as also to the WATS, we have to be very much cautious about the functioning of the foreign educational institutions.

\section{LOOKING AHEAD: PATHWAYS TO A GLOBAL FUTURE}

Even an extreme optimist cannot help but be disheartened by the many problems confronting the Indian higher education system - a vast and unwieldy system comprised of some 300 universities and deemed universities, more than 10,000 colleges and some 6.5 million students. The situation is further complicated by the rigidities of India's centralized higher education bureaucracy, the political pressures on higher education institutions and the growing problem of corruption in various aspects of university life (e.g., admissions, examinations, promotions). In such a beleaguered system, how can internationalization efforts possibly be effective? If India has to emerge as preferred location for higher education in the globalizing world it will have to develop a national policy to address the challenges of sub-standard quality, ineffective systems of monitoring and control, red-tapism in growth and development and political interference.

Three pathways offer some hope and promise for the future. The first path is labeled policy reform. It includes opening up space for private universities, easing or eliminating research restrictions on foreign scholars and graduate students, and encouraging 'foreign collaboration"' in the university sector in the same way such joint ventures now exist in private industry. Stronger partnerships need to be developed between Indian universities and universities in other countries.

A second pathway for Indian internationalists has to do with partnerships. In fields such as engineering, management and computer sciences, for example, industry-university collaborations can yield significant benefits for both sides. A more systematic focus on institutional partnerships could also become part of India's approach to bi-lateral scholarly exchange programs.

The final pathway focuses on innovation and leadership, two qualities in greatest need within Indian higher education today. Innovation can take a variety of forms, ranging from the use of internet technology to develop joint on-line courses between Indian and foreign universities to institutional innovations like the recent initiative by SNDT Women's University to establish an overseas branch campus for women students in the Gulf region. Successful innovation does not take place without leadership. For India to broaden and expand its place in the global 
marketplace of higher education will require bold and innovative leadership by university Vicechancellors, political leaders, administrators and policy makers at the central and state levels.

The need of the hour is not to fight the onset of globalization, but to turn the challenges into opportunities. The best revenge against the forces that cannot be stopped is turning them to our advantage. Education is one area where it can be done effectively. Some of the measures suggested by experts to accomplish this are:

- Liberalize and deregulate the education system,

- De-license higher education, confer institutional autonomy and decentralize syllabus design

- Change the role of Governments into facilitation and supervision through adequate regulatory measures

- Upgrade teacher training, infrastructure and syllabus

\section{CONCLUSION}

There is now increasing global competition for the best and brightest students, as more and more countries recognize the economic potential of higher education as a service export sector and India is not an exception. The major concern of globalization has been "how to fulfill the national objective of equality?" Interaction is expected to improve the quality of education and performance evaluation at all levels of education which is giving more avenues to the private education and in turn affecting the equity consideration. Changes in Indian education system that pervasive the core appears to remain the same only the notion of change and the rate at which it takes place varies virtually and spatially and in field operations. Globalization of higher education may help India to take advantage of opportunities in the new global environment.

With foresight, skill and determination, today's leaders of Indian universities have it within their power to craft a different kind of globalization, one which affirms and values cultural difference and encourages greater mobility for all students. The world of higher education in the $21^{\text {st }}$ century can truly be a border-less world of knowledge and ideas which will yield reciprocal benefits for all nations. There is no single, simple path for reaching this new global future, but instead, multiple pathways that lead toward "a world in one nest".

\section{REFERENCES}

Assocham-Icrier, Joint Conference on Globalization and Higher Education in India, November 1-2, 2006, New Delhi.

Draft Report of Working Group on Higher Education for the XI Plan, Planning Commission, Government of India (2007).

Gaynor, N. (2010). Globalizing higher education: Challenges and contradictions in policy \& practice; A development Education Review, Vol.II

Higher Education and Globalization, $23^{\text {rd }}$ Convocation Address by Dr. Panjab Singh, Oct. 14 2008, Rani Durgawati Vishwavidyalaya, Jabalpur.

Higher education article retrieved from http://en.wikipedia.org/wiki/Higher_education 
http://www.education.nic.in (Department of Education, Government of India.)

Mishra, J. K., Abidi, N. and Sharma, R. (2008). Indian Higher Education: Global Challenges and Local Issues. JBS Working Paper Series.

Safaya, R. (2002). Current problems in Indian Education, Dhanpat Rai Publishing Co: New Delhi.

Scott, P. (1998). Classification, Internationalization and Globalization, in P. Scott (ed.), The Globalization of Higher Education, The Society for Research into Higher Education/Open University Press, Buckingham, pp. 108- 129.

Sharma, V. (2007). Indian Higher Education: Commodification and foreign direct investment. The Marxist, Vol.XXIII, No. 02.

Takwale, R. (2002). Presidential Address on 'Convergence of Educational Modes - An Opportunity for Evolving New Paradigm of Education’ at the IDEA 2002 Conference held at University of Jammu, Jammu, during 1-3 March 2002.

Teichler, U. (2004), .The Changing Debate on Internationalization of Higher Education. Higher Education, Vol. 48, pp. 5-26.

Tilak, J.B.G. (2002). Education and Globalization: The changing concerns in Economics of Indian Education. Perspectives in Education, Vol. 17, Special Issue pp. 05-08.

Valimaa, J. (2004). Nationalization, Localization and Globalization in Higher Education. Higher Education, Vol. 48, pp. 27-54. 